\title{
Flipped Classroom Sebagai Strategi Pembelajaran Pada Era Digital
}

\author{
Susanti, L ${ }^{1,}$ Hamama Pitra, DA ${ }^{2}$ \\ ${ }^{1}$ Bagian Neurologi/ Medical Education Unit Fakultas Kedokteran Universitas Andalas, Padang, Indonesia \\ E-mail : lydiasusanti99@gmail.com \\ ${ }^{2}$ Bagian Neurologi/ Medical Education Unit Fakultas Kedokteran Universitas Baiturrahmah, Padang, Indonesia
}

\begin{abstract}
Abstrak
Latar belakang: Revolusi digital memiliki pengaruh penting di bidang pendidikan seperti pada bidang lainnya. Pengaruh ini juga menyebabkan perubahan radikal di bidang pendidikan, seperti dalam hal pendekatan pengajaran dan pembelajaran. Flipped classroom merupakan suatu strategi pembelajaran yang tergolong baru. Strategi pembelajaran ini semakin berkembang dengan kemajuan teknologi, seperti akses internet serta software yang pendukung lainnya. Pada pembelajaran tradisional pendidik menyampaikan materi, lalu untuk menambah pemahaman materi tersebut maka siswa akan mengerjakan tugas di sekolah dan diberikan pekerjaan rumah. Pada flipped classroom, peserta didik berpartisipasi dalam mempersiapkan pembelajaran melalui tontonan video, memahami powerpoint dan mengakses sumber belajar yang disediakan oleh pendidik baik melalui media online seperti e-learning. Beberapa penelitian membuktikan bahwa penerapan Flipped classroom dapat meningkatkan motivasi belajar peserta didik. Tujuan: Tujuan: Untuk meninjau secara singkat semua informasi terkini tentang flipped classroom di era digital. Kesimpulan: Revolusi digital memiliki pengaruh penting di bidang pendidikan seperti di banyak bidang lainnya. Pengaruh ini juga menyebabkan perubahan radikal di bidang pendidikan, seperti dalam hal pendekatan pengajaran dan pembelajaran, sehingga pendidik perlu menciptakan bentuk pembelajaran aktif yang sesuai dengan karakteristik peserta didik zaman ini.
\end{abstract}

Katakunci - Metode Pembelajaran - Era Digital - Flipped Classroom

\begin{abstract}
Background: Digital revolution has an important impact in the education strategy as in many other fields. This impact also led to radical changes in the field of education, such as in terms of teaching and learning approaches. Flipped classroom is a new learning strategy. This learning strategy is increasingly developing with technological advancements, such as internet access and other supporting software. In traditional learning educators deliver material, then to increase understanding of the material then students will do the assignments at school and given homework. On flipped classroom, students participate in preparing learning through video viewing, understanding powerpoints and accessing learning resources provided by educators through online media such as e-learning. Several studies have shown that the application of Flipped classroom can improve students' learning motivation. Objective: to briefly review all current information about flipped classroom in digital era. Conclusion: The digital revolution has had an important impact on education as in many other fields. This influence also causes radical changes in the field of education, such as in terms of teaching and learning approaches, so that educators need to create forms of active learning that are in accordance with the characteristics of today's students.
\end{abstract}

Keywords - Digital era, Flipped classroom, Teaching strategy

Health \& Medical Journal 


\section{Pendahuluan}

Revolusi digital memiliki pengaruh penting di bidang pendidikan seperti di banyak bidang lainnya. Pengaruh ini juga menyebabkan perubahan radikal di bidang pendidikan, seperti dalam hal pendekatan pengajaran dan pembelajaran. Para peserta didik di zaman ini memiliki karakteristik yang sangat berbeda jika dibandingkan dengan masa lalu, oleh karena itu, cukup sulit untuk menarik minat dan keingintahuan siswa hari ini untuk kegiatan pembelajaran melalui pendekatan pengajaran tradisional. Selain itu, tidak mudah untuk mengatasi beberapa masalah terkait mengajar dan belajar dengan pendekatan yang sudah ketinggalan ini. ${ }^{1}$

Para pendidik saat ini menunjukkan minat yang sangat besar pada pendekatan pengajaran inovatif yang menjawab kebutuhan zaman ini. Salah satu pendekatan tersebut adalah model flipped classroom. Flipped classroom merupakan suatu strategi pembelajaran yang tergolong baru. Strategi pembelajaran ini semakin berkembang dengan kemajuan teknologi, seperti akses internet serta software yang pendukung lainnya. Pada pembelajaran tradisional pendidik menyampaikan materi, lalu untuk menambah pemahaman materi tersebut maka siswa akan mengerjakan tugas di sekolah dan diberikan pekerjaan rumah. Pada flip classroom, peserta didik berpartisipasi dalam mempersiapkan pembelajaran melalui tontonan video, memahami powerpoint dan mengakses sumber belajar yang disediakan oleh pendidik baik melalui e-learning atau cara lainnya. Setelah memiliki persiapan yang lengkap di rumah, maka di kelas peserta didik akan mampu untuk menyelesaikan masalah (problem solving), menganalisis serta memberikan solusi terhadap permasalahan yang dihadapi. Terdapat dua komponen dalam flipped classroom yaitu "memindahkan pendidikan ke luar kelas" biasanya pembelajaran dihantarkan melalui media elektronik dan memindahkan praktek berupa tugas dan pekerjaan rumah ke dalam kelas. ${ }^{2}$

\section{Tinjauan Pustaka}

Flipped classroom adalah strategi pembelajaran yang menggunakan jenis pendekatan pembelajaran campuran (blended learning) dengan membalikkan lingkungan belajar tradisional dan memberikan konten pembelajaran di luar kelas (sebagian besar online). Selama sesi tatap muka di kelas, dilakukan pembahasan terhadap tugas (bahan yang secara tradisional dianggap sebagai pekerjaan rumah) atau pendidik dapat meminta kelas untuk membahas pertanyaan ujian terkait. Beberapa pendidik juga melakukan kegiatan menonton video kuliah streaming atau berkolaborasi dalam diskusi online sebagai kegiatan kelas dengan pengawasan cermat oleh fasilitator. ${ }^{3,4}$

Strategi ini memiliki dua langkah besar: ${ }^{3}$

- Tugas pekerjaan rumah: bahan bacaan yang relevan (online atau hardcopy) yang berkaitan dengan topik kuliah diberikan kepada peserta didik sebagai pekerjaan rumah; alternatif lain, peserta didik diminta untuk meninjau video untuk diskusi selanjutnya di kelas.

- Kegiatan di dalam kelas: Selama kegiatan kuliah, sesi tanya jawab dilakukan berdasarkan tugas pekerjaan rumah; sesi ini difasilitasi oleh pendidik. Namun, kadang-kadang kegiatan di dalam kelas dapat berupa sesi pemecahan masalah berdasarkan topik kuliah. ${ }^{3}$

Pada pendekatan baru ini, peserta didik menonton video yang berubungan dengan materi yang dipelajari dan mempersiapkan pertanyaan atau permasalahan yang tidak mereka mengerti. Pada saat di kelas, peserta didik berperan dalam kegiatan aktif, seperti problem solving (individu atau grup), diskusi atau kegiatan kelompok. ${ }^{5}$

$\mathrm{Chi}^{6}$ menunjukkan bahwa flipped classroom 
adalah alternatif untuk pedagogi konvensional, yang mengharuskan peserta didik memperoleh informasi dengan melihat video instruksional sebelum pertemuan fisik di kelas dan memungkinkan peserta didik menerapkan pengetahuan itu di kelas, sehingga melibatkan peserta didik dalam tatanan aktif yang lebih tinggi, kegiatan yang konstruktif dan interaktif. Peningkatan interaksi melalui pembelajaran aktif dapat meningkatkan retensi pengetahuan. Pada tabel 1 Terlihat perbandingan antara kelas tradisional dan flipped classroom. ${ }^{6}$

TABEL 1. GaMbaRAN KEgIATAN PEMBELAJARAN FLIPPED CLASSROOM DIBANDINGKAN DENGAN KELAS TRADISIONAL $^{6}$

\begin{tabular}{|c|c|c|c|}
\hline & $\begin{array}{l}\text { Before the } \\
\text { class }\end{array}$ & $\begin{array}{l}\text { During the } \\
\text { class }\end{array}$ & $\begin{array}{l}\text { Shortly } \\
\text { before }\end{array}$ \\
\hline $\begin{array}{l}\text { Traditio } \\
\text { nal }\end{array}$ & $\begin{array}{l}\text { Surface } \\
\text { learning: } \\
\text { (compulsory) }\end{array}$ & $\begin{array}{l}\text { Surface } \\
\text { learning: } \\
\text { listening to } \\
\text { the lecture, } \\
\text { taking notes }\end{array}$ & $\begin{array}{l}\text { Construct } \\
\text { understandin } \\
g: \text { studying } \\
\text { materials }\end{array}$ \\
\hline Flipped & $\begin{array}{l}\text { Construct } \\
\text { understandin } \\
\text { g via } \\
\text { assignment : } \\
\text { watching } \\
\text { video clips, } \\
\text { reading, and } \\
\text { preparing/su } \\
\text { bmitting } \\
\text { questions }\end{array}$ & $\begin{array}{l}\text { Construct } \\
\text { understandin } \\
\text { g: } \\
\text { Answering } \\
\text { (clicker) } \\
\text { questions, } \\
\text { peer- } \\
\text { instruction, } \\
\text { and } \\
\text { discussions }\end{array}$ & $\begin{array}{l}\text { Reinforcemen } \\
\text { t of } \\
\text { understandin } \\
g: \\
\text { Studying and } \\
\text { recapping } \\
\text { discussed } \\
\text { questions and } \\
\text { problems }\end{array}$ \\
\hline
\end{tabular}

*For Investigating the effects of flipped class, a traditional course with five traditional lectures per week was compared with a course in which one of the five traditional lectures per week was replaced by flipped lecture

Sumber : Van Vliet, EA, Winnips, JC \& Brouwer N. Flipped-class pedagogy enhances student metacognition and collaborative-learning strategies in higher education but effect does not persist. CBE Life Sci Educ. 2015. 14(3):1-10

Kemajuan teknologi membuat pendidik lebih mudah menerapkan konsep flipped classroom. Kuliah web dan video penjelasan singkat saat ini tersedia secara online, menjadikan teknologi ini lebih umum di dunia akademis. Tucker ${ }^{7}$ bergagumentasi bahwa pengajar tidak perlu mempersiapkan video perkuliahan, namun bisa dengan mudah mengunggah dari internet, misalnya dari khan academy, youtube atau ted. ${ }^{7}$

Perkembangan teknologi saja tidak cukup. Perubahan terbesar juga diperlukan dalam diri pendidik. Pendidik perlu memberikan struktur dan memfasilitasi peserta didik untuk mencapai tujuan belajar, mendorong peserta didik mempersiapkan pembelajaran melalui video pendek, mengajukan pertanyaan, dan mengorganisir diskusi yang memungkinkan peserta didik mendapatkan umpan balik tentang pencapaiannya. Tujuannya adalah untuk menstimulasi pembelajaran yang mendalam dan mengubah strategi pembelajaran melalui kegiatan di dalam kelas, misalnya diskusi. ${ }^{6}$

Pendekatan flipped classroom tidak merubah konsep pedagogik. Ia hanya merubah peran peserta didik dari pendengar pasif saat di kelas, menjadi berpartisipasi aktif dalam kegiatan pembelajaran. Menurut Tucker ${ }^{7}$ keuntungan penting dari flipped classroom adalah mendukung kerjasama tim dan diskusi dalam kelas, peserta didik dapat menonton video dimanapun dan kapanpun ia mau, ia bisa mengatur kecepatan belajar sesuai dengan kebutuhannya, mendorong peserta didik untuk berfikir, baik di dalam maupun di luar kelas. Dan mereka berkesempatan menggunakan berbagai strategi pembelajaran. Sistem pembelajaran ini membuat pengajar memiliki waktu berinteraksi lebih banyak dengan peserta didik dan dapat memahami kebutuhan emosional peserta didik. ${ }^{7}$

Bloom mengembangkan konsep pembelajaran, yang digambarkan sebagai piramida dengan berbagai tingkat pembelajaran. Ini biasanya disebut sebagai "taksonomi Bloom". Kerangka kerja ini sering digunakan sebagai lensa untuk melihat berbagai tahapan pembelajaran. Proses belajar dari akuisisi pengetahuan hingga kegiatan berpikir kritis direvisi oleh Lorin Anderson pada 1990-an. Versi revisi dari Taksonomi Bloom ini relevan dengan flipped clasroom karena transmisi informasi, yang merupakan dasar untuk pembelajaran, 
diperoleh secara mandiri dan di luar kelas; sedangkan asimilasi informasi, yang membutuhkan penalaran kritis yang lebih besar terjadi selama kelas di bawah bimbingan seorang instruktur atau mentor. Semakin tinggi tingkat yang digambarkan pada piramida, semakin banyak asimilasi diperlukan; sedangkan, semakin rendah levelnya, semakin banyak transmisi informasi yang terjadi secara mandiri, tetapi tidak sepenuhnya, dari asimilasi. area di tengah mungkin membutuhkan kombinasi keduanya yang lebih seimbang atau kurang miring. ${ }^{1}$

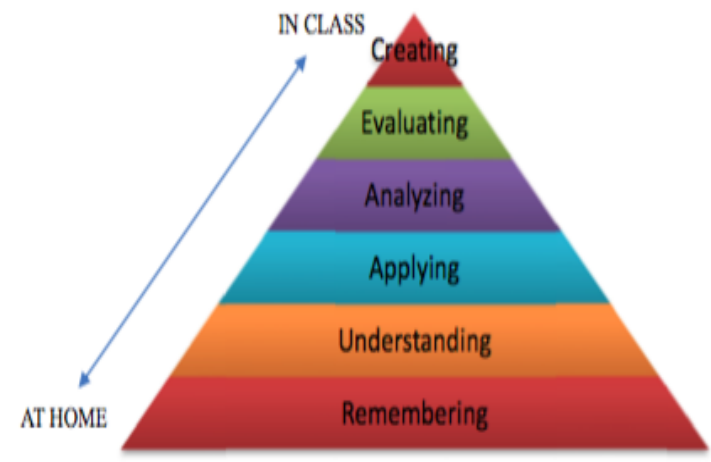

Gambar 1. Taksonomi Bloom dan Model Flipped classroom. ${ }^{1}$

Taksonomi Bloom menunjukkan tahapan dan jenis pembelajaran yang terjadi pada setiap tahap, namun tidak menjelaskan bagaimana cara flipped classroom menguasai setiap level dalam konteks tertentu. Manfaat dari pembelajaran flipped classroom sehubungan dengan taksonomi Bloom adalah bahwa peserta didik secara aktif dibantu selama beberapa kegiatan yang membutuhkan pemikiran tingkat tinggi. ${ }^{8}$

Cognitif task memegang peranan penting dalam belajar dengan menggunakan konsep flipped classroom. Secara umum, level kognitif tingkat rendah (remember, understanding) terbentuk diluar kelas sementara level kognitif tingkat tinggi terbentuk didalam kelas (application, analysis, evaluation, creation) seperti yang terlihat pada gambar 2.1. ${ }^{1}$

Disamping kelebihan dari flipped classroom, juga terdapat sejumlah tantangan dalan menerapkan flipped classroom. Tantangan terbesar yang dirasakan adalah dalam mempersiapkan materi kuliah melalui video, visual dan materi tertulis memerlukan waktu yang cukup panjang, terutama pada tahun pertama penerapan flipped classroom di institusi. Pada penerapan flipped classroom pada tahun-tahun berikutnya, pendidik dapat menggunakan materi sebelumnya bila tida ada revisi dalam pengajaran. Selain itu terdapat kecemasan peserta didik dalam pelaksanaan flipped classroom karena mereka harus menonton video dan menyelesaikan membaca bacaan yang disediakan sebelum pertemuan di kelas. Seharusnya hal ini tidak dianggap sebagai sebuah kerugian dalam flipped classroom, karena situasi ini bermanfaat untuk meningkatkan pembelajaran. Bland ${ }^{9}$ beranggapan bahwa peserta didik mungkin mengalami kesulitan dalam memenuhi tanggung jawab dan harapan pendidik dalam model flipped classroom. Dalam hal ini diperlukan transisi bertahap dalam penerapan flipped classroom, berbagi tanggung jawab dengan cara yang menyenangkan,, berbagi tugas dengan cara yang jelas, dan memberikan reward bisa memfasilitasi masa transisi. Pada beberapa situasi, peserta didik memiliki tantangan dalam penerapan flipped classroom karena tidak memiliki akses terhadap teknologi internet. Tantangan terakhir yang juga dihadapi adalah sikap peserta didik yang belum bisa menerima flipped classroom karena mereka merasa sudah nyaman dengan kelas tradisional yang merupakan pembelajaran pasif. ${ }^{9}$

\section{KeSIMPULAN}

Revolusi digital memiliki pengaruh penting di bidang pendidikan seperti di banyak bidang lainnya. Pengaruh ini juga menyebabkan perubahan radikal di bidang pendidikan, seperti dalam hal pendekatan pengajaran dan pembelajaran, sehingga pendidik perlu menciptakan bentuk pembelajaran aktif yang sesuai dengan 
karakteristik peserta didik zaman ini. Flipped classroom adalah strategi pembelajaran yang menggunakan jenis pendekatan pembelajaran campuran (blended learning) dengan membalikkan lingkungan belajar tradisional dan memberikan konten pembelajaran di luar kelas (sebagian besar online), dengan memanfaatkan kemajuan teknologi.

\section{Daftar Pustaka}

[1] Cevikbas M \& Argun Z. An Innovative Learning Model in Digital Age : Flipped Classroom. Journal education and Training Studies. 5(11):189-200

[2] Educause. Things You Should Know About Flipped Classrooms.2012. Retrieved from http://net.educause.edu/ir/library/pdf/

ELI7081.pdf, diunggah pada tanggal 1 Mei 2019.

[3] Samaraseka DD, Gwee MCE, Long A, Lock B. Lectures and Large Group. In: Swanwick $\mathrm{T}$, Forrest K, O'Brien BC. Understanding Medical Education: Evidence, Theory, and Practice Third Edition. Wiley Blackwell. 2019 ; 113-121

[4] Chen Hsieh, J. S., Huang, Y.-M., \& Wu, W.-C. V. (2017). Technological acceptance of LINE in flipped EFL oral training. Comput Hum Behav. 2017; $\quad 70 \quad: 178-190$. doi.org/10.1016/j.chb.2016.12.066

[5] Sohrabi B \& Iraj H. Implementing flipped classroom using digital media: A comparison of two demographically different groups perceptions. Comput Hum Behav. 2016; 60: 514 524. doi.org/10.1016/j.chb.2016.02.056

[6] Van Vliet, EA, Winnips, JC \& Brouwer N. Flipped-class pedagogy enhances student metacognition and collaborative-learning strategies in higher education but effect does not persist. CBE Life Sci Educ. 2015. 14(3):1-10. doi: 10.1187/cbe.14-09-0141

[7] Tucker B. The flipped classroom. EdNext. 2012 ;12(1) :82-3

[8] Eppard J \& Rochdi A. A Framework for Flipped Learning. 13th International Conference Mobile Learning 2017

[9] Davies RS, Dean DL \& Ball N. Flipping the classroom and instructional technology integration in a college-level information systems spreadsheet course. Educ Technol Res Dev. 2013. 61(4) ; 563-580. https://doi.org/10.1007/s11423013-9305-6

[10] Schmidt \& Stacy MP. The Flipped Classroom: A Twist on Teaching. Contemp Issues Educ Res. 2016. 9(1);1-10

[11] Albers GW, et al. Antithrombotic Therapy in Atrial Fibrillation. Chest. 2001;119:194S-206S.
[12] Golomb MR. Strokes in Neonates and Children: Overview. In: Biller J, $2^{\text {nd }}$ ed. Stroke in Children and Young Adults. 2009. Philadelphia: Saunders Elsevier

[13] Uduma UF, Mbiydzela, Ernest Ngu, Mathieu M, Wali M. Childhood Ischemic Stroke: a Report of Two Cases. Global Journal of Health Sciences 2011;3:2:200-205 